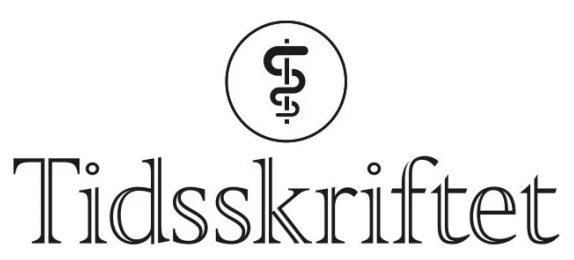

DEN NORSKE LEGEFORENING

\title{
Bengt I. Lindskog
}

\author{
MINNEORD
}

BRITTA STENSTAM

STEFAN LEANDER

LARS MALM

MARIANNE EHINGER

BERNDT EHINGER

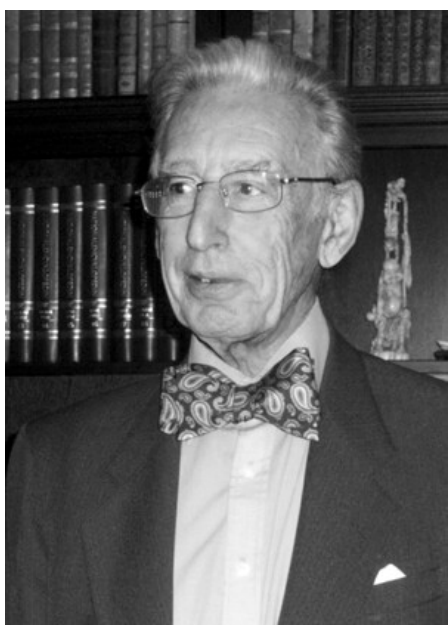

Bengt I. Lindskog på Lärkvägen i Hjärup har avlidit efter en kort tids sjukdom. Han blev drygt 92 år och sörjs närmast av barnen Alf, Gunilla, Stefan och Catharina samt sin livskamrat de sista åren, Gunnvi Crona.

Polyhistor är ett gammalt fint ord som väcker respekt. I gamla tider fanns det mer än en sådan, i Sverige kanske framför allt Carl von Linné. Bengt Lindskog framstår som något av en polyhistor. Han hade litterära och språkliga intressen från mödernet och medicinska sådana från fädernet. Han kombinerade dessa under sitt långa liv genom att bli läkare och språkman. Han blev docent i kirurgi 1972, men övergick snart till att bli överläkare i socialmedicin på Lasarettet i Lund och därefter mångårig överläkare och chef för Företagshälsan i staden. 
Som språkman utarbetade han ett antal mycket uppmärksammade, väl spridda och omfångsrika medicinska ordböcker. Det blev många skrifter i medicinsk humaniora, inklusive medverkan i en bok om Carl von Linnés skrift Clavis medicinae duplex.

Verksamheten kulminerade i en professur i medicinens historia i Köpenhamn 1988-96. År 2001 invaldes han i Kungliga Fysiografiska Sällskapet.

Dessförinnan hade Bengt Lindskog 1964 varit en av dem som grundade Sydsvenska Medicinhistoriska Sällskapet i Lund. Han var 2001 också en av stiftarna till den sociala vänföreningen Skånes äldre läkare, Skåne-SÄL.

Bengt Lindskog stödde under många år Sydsvenska Medicinhistoriska Sällskapet, inte bara som aktiv skribent i sällskapets årsskrifter utan också genom att donera generösa medel till en stiftelse för främjande av utvecklingen av kunskapen om medicinens historia och vårdandet av svenskt medicinskt språk. Viktiga delar av hans omfattande och värdefulla bibliotek har han överlåtit till sällskapet. Utan att tveka ställde han också sitt encyklopediska vetande till förfogande för allehanda medicinhistoriska berättelser och notiser. Han var därtill under flera år engagerad i styrelsen för Läkaresällskapet i Lund. Han blev hedersledamot i tre olika sällskap med samhällstillvända aktiviteter: Läkaresällskapet i Lund, Heimdall i Malmö och Sydsvenska Medicinhistoriska Sällskapet. Så sent som september 2021 höll han en lättsam och engagerande föreläsning för sina kollegor i SkåneSÄL om hur han tjugo år tidigare agerade när föreningen bildades.

När Region Skåne 2006 stängde det dåvarande medicinhistoriska museet i Lund, gjorde Bengt Lindskogs entusiasm och stora sociala och medicinhistoriska kompetens honom till ett starkt stöd för Sydsvenska Medicinhistoriska Sällskapet så att detta fick styrfart nog att 2012 kunna öppna en medicinhistorisk utställning i Lund, Livets Museum.

Vi minns Bengt I. Lindskog med värme och tacksamhet. Han var sina många vänners vänfasta vän och gav ett starkt stöd när det behövdes. Han går till historien som engagerad medicinhistoriker, stor medicinsk språkman och framstående humanist.

För Sydsvenska Medicinhistoriska Sällskapet.

Publisert: 28. februar 2022. Tidsskr Nor Legeforen. DOI: 10.4045/tidsskr.22.0077

(C) Tidsskrift for Den norske legeforening 2023. Lastet ned fra tidsskriftet.no 26. april 2023. 